\title{
Pengaruh Partisipasi Penyusunan Anggaran Terhadap Kinerja Manajerial Pada RSUD Wilayah Bogor
}

\author{
Riyani Satriyanti Saputri ${ }^{1}$, Sri Hartoyo ${ }^{2}$, dan Hendro Sasongko ${ }^{3}$ \\ Sekolah Bisnis Institut Pertanian Bogor University ${ }^{1,2}$ \\ Universitas Pakuan Bogor ${ }^{3}$ \\ Email: saputririyani96@gmail.com
}

\begin{abstract}
This study aims to determine and analyze the role of participation in budgeting on managerial performance where in this study there is a moderating variable that is Reward in BLUD RSUD Bogor region. The data obtained were processed using Microsoft Excel 2018 and Eviews. The sampling technique with purposive sampling technique. The results obtained after a study of 85 respondents using multiple linear regression analysis models explained that there is an influence of participation in budgeting on managerial performance. Budgeting can act as a planning and performance criteria, where the budget can be used as a control system to measure managerial performance. This means that participatory budgeting can be assessed as a managerial approach that can improve the performance of each manager as an individual, and reward does not affect managerial performance. Continue to evaluate the performance using the Balance Scorcard seen from the main performance indicators and achieve performance for the realization of performance achievements included in the predicate is very good in 2017-2018.
\end{abstract}

Keywords: participation in budgeting, managerial performance, reward.

\begin{abstract}
Abstrak: Penelitian ini menganalisis pengaruh partisipasi dalam penyusunan anggaran dan terhadap kinerja manajerial pada BLUD RSUD wilayah. Data yang diperoleh diolah menggunakan Microsoft Excel 2018 dan Eviews. Teknik pengambilan sampel dengan teknik purposive sampling. Hasil yang diperoleh setelah dilakukan penelitian terhadap 85 responden menggunaka model analisi regresi linier berganda menjelaskan bahwa terdapat pengaruh partisipasi dalam penyusunan anggaran terhadap kinerja manajerial, Penyusunan anggaran dapat berperan sebagai perencanaan dan kriteria kinerja, dimana anggaran dapat dipakai sebagai suatu sistem pengendalian untuk mengukur kinerja manajerial. Hal ini berarti anggaran partisipatif dapat dinilai sebagai pendekatan manajerial yang dapat meningkatkan kinerja setiap manajer sebagai individual, serta Reward tidak berpengaruh terhadap kinerja manajerial. Selanjutkan untuk evalusi kinerja menggunakan Balance Scorcard dilihat dari indikator kinerja utama dan capai kinerja untuk realisasi capaian kinerja masuk dalam predikat sangat baik pada tahun 2017-2018.
\end{abstract}

Kata kunci: Partisipasi penyusunan anggaran, kinerja manajerial, reward.

\section{PENDAHULUAN}

Persaingan dunia usaha yang semakin ketat, sehingga setiap perusahaan harus menetapkan suatu perencanaan dalam setiap kegiatan yang akan dilaksanakan sebagi 
pencapaian tujuan. Oleh sebab itu manajemen berkewajiban mengendalikan dan mempertahankan kelangsungan hidup perusahaan sehingga tujuan yang ditetapkan tercapai agar perusahaan tetap unggul dalam persaingan dengan cara melakukan peningkatan kinerja. Perusahaan dapat terlebih dahulu melakukan peningkatan kinerja dengan menentukan sasaran yang akan dicapai agar kinerjanya dapat diukur. Sasaran tersebut dituangkan dalam visi dan misi perusahaan yang menjadi tolak ukur keberhasilan dalam menjalankan kegiatannya. Pengukuran kinerja dilakukan sebagai cara pengendalian dalam mengumpulkan dan menyampaikan informasi untuk membuat laporan kegiatan seta membandingkan dengan rencana yang sudah ditetapkan sebelumnya untuk menilai efektivitas dan efisiensi perusahaan. Kinjera suatu organisasasi merupakan kinerja setiap individu yang melakukan kegiatan-kegiatan manajerial sebagai penentu keberhasilan organisasi yaitu seorang manajer yang harus mengerjakan kegiatan manajemen dengan sebaik mungkin meliputi, perencanaan, pengorganisasian, memimpin dan mengendalikan.

Menurut (Yogi, 2018) salah satu alat perencanaan yaitu anggaran. Perencaaan anggaran merupakan kegiatan yang telah ditetapkan seseui dengan jumlah target dan sasaran yang akan dicapai oleh suatu perusahaan dalam melaksanakan serangkaian kegiatan tertentu pada masa yang akan dating. Proses dalam penyusunan anggaran dapat dilakukan dengan beberapa pendekatan yaitu pendekatan dari atas ke bawah (Top Down Approach), pendekatan dari bawah ke atas (Bottom Up Approach) dan pendekatan partisipasif campuran, yang merupakan kombinasi dari keduanya. Penyusunan anggaran tidak boleh hanya dilakukan oleh manajer puncak tetapi harus didukung dengan peran serta secara aktif para manajer tingkat menengah dan bawahannya sesuai dengan kompetensinya masingmasing. Jika penyusunan anggaran hanya berdasarkan kehendak atasan tanpa melibatkan partisipasi bawahan maka dapat menimbulkan kesulitan bagi bawahan untuk mencapainya. Sebaliknya jika penyusunan anggaran hanya disusun sesuai kehendak bawahan maka juga dapat menimbulkan rendahnya motivasi bawahan dalam mencapai target-target yang optimal (Zuwesty, 2015). Menurut (Rahayu dan Andry, 2013) anggaran partisipatif melibatkan seluruh karyawan dari semua tingkatan manajer dalam organisasi dalam proses penyusunan anggaran. Kinerja manajerial yang baik mengindikasikan bahwa target anggaran tercapai. Suatu anggaran menjadi suatu alat dalam membantu manajemen mengkomunikasikan, mengkoordinasikan dan untuk mengevaluasi tujuan organisasi semua manajer dari tingkat menegah dan unit organisasi dibawahnya (Nafinia, 2016). Berpartisipasi dalam penyusunan anggaran bawahan mendapatkan kesempatan dalam proses pencapain anggaran, sehingga kinerja manajerial dikatakan efektif jika tujuan anggaran dapat tercapai sesuai dengan sasaran perusahaan. Hubungan partisipasi dalam penyusunan anggaran dengan kinerja manajerial adalah dengan penyusunan anggaran yang dilakukan dengan partisipasi diharapkan akan meningkat kinerja manajer, dimana ketika suatu tujuan dirancang dan dilakukan secara partisipasi, maka karyawan akan menginternalisasikan tujuan-tujuan yang ditetapkan, dan memiliki rasa tanggung jawab pribadi untuk mencapainya, karena mereka ikut terlibat dalam penyusunan anggaran (Hanifatuz dan Indira, 2016). Namun demikian, bukti empiris menunjukkan adanya hubungan antara anggaran partisipatif dengan peningkatan kinerja manajerial (Nanik, 2017).

Rumah Sakit Umum Daerah (RSUD) yaitu badan penyedia layanan kesehatan yang disediakan oleh pemerintah daerah. RSUD sebagai menjadi salah satu badan yang berfungsi memberikan layanan kesehatan sesuai dengan standar yang telah ditentukan pemerintah. 
Menurut undang-undang RI. No. 44 Tahun 2009 tentang Rumah Sakit, menyatakan bahwa fungsi rumah sakit sebagai pelayanan pengobatan dan pemulihan kesehatan, pemeliharaan dan peningkatan kesehatan sesuai paripurna tingkat kedua dan ketiga berdasarkan kebutuhan medis, penyelenggaraan pendidikan dan pelatihan sumber daya manusia dalam untuk meningkatkan pelayanan kesehatan, penyelenggaraan penelitian dan pengembangan serta penapisan teknologi bidang kesehatan dalam meningkatkan layanan kesehatan sesuai etika ilmu pengetahuan bidang kesehatan.

Badan Layanan Umum Daerah merupakan bagian dari perangkat pemerintah daerah, yang tidak terpisah dari pemerintah daerah. Pola Pengelolaan Keuangan Badan Layanan Umum Daerah adalah pola pengelolaan keuangan yang memberikan fleksibilitas berupa keleluasaan untuk menerapkan praktek-praktek bisnis yang sehat untuk meningkatkan pelayanan kepada masyarakat dalam rangka memajukan kesejahteraan umum dan mencerdaskan kehidupan bangsa. Praktek bisnis sehat yang dimaksud adalah penyelenggaraan fungsi organisasi berdasarkan kaidah-kaidah manajemen yang baik pada Rumah Sakit dalam rangka pemberian layanan yang bermutu dan berkesinambungan. Dalam pengelolaan keuangan, BLUD diberikan fleksibilitas antara lain berupa pengelolaan pendapatan dan biaya, kas, utang, piutang, sisa kas di akhir tahun anggaran, pengadaan barang dan/atau jasa penyusunan akuntansi, pelaporan dan pertanggungjawaban, pengelolaan dana secara langsung.

Salah satu tantangan saat ini dihadapi manajemen RSUD tergambar dari seluruh karyawan harus mengubah pola pikir, dari karyawan swasta menjadi karyawan rumah sakit yang berkewajiban mengedepankan pelayanan social. Jika karyawan tidak merubah pola piker dan sikap bertahan maka akan mempersulit dalam pemberan pelayanan kepada pasien. Di masa transisi ini, manajemen RSUD juga menghadapi tuntutan untuk segera menyusun standar kinerja manajerial, maupun pelayan medis atau sejenis SOP. Mereka perlu menyusun standar dalam meningkatkan kinerja manejerial sesuai dengan sasaran yang sudah ditetapkan.

Kemudian harus ada penyesuaian antara tarif pelayanan medis yang ditetapkan rumah sakit dengan tarif yang ditetapkan dalam BPJS. Rumah sakit harus bisa mensubsidi setiap biaya yang dibutuhkan oleh pasien. Sebab tuntutan yang ditujukan kepada pengelola BPJS tidak bias menutupi biaya yang dikeluarkan oleh pasien. Adanya kesenjangan tarif menyebabkan subsidi yang dikeluarkan untuk pasien p cenderung lebih besar. Berdasarkaan data yang diperoleh diketahui lebih dari $80 \%$ pasien yang datang, merupakan peserta BPJS. Kekurangan anggaran kesehatan (BPJS) diperkirakan semakin membesar tahun 2020. Angka defisit pada 2019 diperkirakan mencapai Rp28 triliun. Perhimpunan Rumah Sakit Seluruh Indonesia (Persi) sudah mengusulkan agar pemerintah memberikan kucuran dana lebih setiap bulan. Dana sebesar Rp2 triliun itu diharapkan bisa menutupi selisih antara premi iuran dengan klaim yang harus dibayar BPJS Kesehatan .Usulan ini menjadi salah satu poin solusi jangka pendek yang diajukan Persi ke pemerintah. Dampak defisit anggaran BPJS akan mengakibatkan seretnya kebutuhan obat dan anggaran untuk gaji karyawan dikhawatirkan semakin mengurangi kualitas pelayanan bagi pasien dan kualitas manajerial RSUD itu sendiri. Hutang selama semester pertama 2019 mencapai Rp 7,1 triliun per 8 Juli 2019. Angkanya diklaim sudah turun dalam berita acara BPJS Kesehatan per tanggal 14 Juli 2019 menjadi tinggal Rp 6,5 triliun. Jumlahnya sendiri masih terbilang besar karena ada akumulasi dengan tahun 2018. Sedangkan tunggakan badan penyelenggara jaminan sosial (BPJS) kesehatan menunggak menunggak tagihan sekitar Rp27 miliar ke Rumah Sakit 
Umum Daerah (RSUD) wilayah Bogor, Jawa Barat. Tunggakan itu untuk pembayaran pasien medio Juli-Agustus 2019. Kepala Bagian Keuangan RSUD wilayah Bogor, Rifki, mengatakan persoalan likuiditas BPJS Kesehatan berakibat pada tunggakan pembayaran tagihan ke RSUD. Ia juga menuturkan, untuk mengatasi masalah tunggakan oleh BPJS Kesehatan, RSUD wilayah Bogor bekerja sama dengan perbankan terkait dana talangan untuk pembiayaan. Sehingga dengan dana talangan tersebut kegiatan operasional RSUD tidak terganggu. Intinya operasional RSUD harus tetap bisa melayani kesehatan.

Pemerintah kota Bogor telah membahas dengan jajaran SKPD (Satuan Kerja Perangkat Daerah). Pemkot Bogor mengagendakan rapat evaluasi untuk memahami detail apa permasalahan-permasalahan itu. (Serapan anggaran yang kurang) biasanya kondisikondisi yang tidak sejalan antara capaian fisik dan anggaran.Dinas yang memiliki anggaran cukup tinggi seperti Dinas Pendidikan (Disidik), Dinas Kesehatan (Dinkes) dan Dinas Pekerjaan Umum dan Perumahan Rakyat (PUPR). Berdasarkan data yang diperoleh terkaitserapan anggaran hingga September 2019 dengan komposisi sebagai berikut:

Tabel 1. Serapan Anggaran September 2019 (dalam rupiah)

\begin{tabular}{|c|c|c|c|c|}
\hline No & Bidang & Anggaran & Realisasi & Persentase \\
\hline 1 & Inspektorat & 13.989.422.000. & 9.971 .728 .051$. & $76.28 \%$ \\
\hline 2 & $\begin{array}{l}\text { Rumah Sakit Umum } \\
\text { Daerah (RSUD }\end{array}$ & 294.292.177.000. & 5.876.581.273. & $12.21 \%$ \\
\hline 3 & Dinas Pendidikan & 627.055.947.000. & 309.327.364.089. & $49.41 \%$ \\
\hline 4 & $\begin{array}{l}\text { Kantor Kesatuan } \\
\text { Bangsa dan Politik } \\
\text { (KKBP) }\end{array}$ & 4.585.020.000. & 2.331.003.175. & $60.01 \%$ \\
\hline
\end{tabular}

Berdasarkan tabel 1 dijelaskan bahwa bidang Inspektorat menyerap anggaran tertinggi dengan Rp 9.971.728.051atau 76.28\% persen dari Rp 13.989.422.000. Sedangkan, serapan anggaran terkecil berada di Rumah Sakit Umum Daerah (RSUD) dengan Rp 35.876.581.273atau hanya 12.21\% dari Rp 294.292.177.000. Alasannya karena serapan anggaran yang kurang biasanya kondisi-kondisi yang tidak sejalan antara fisik dan anggran. SKPD cenderung merealisasikan serapan anggaran sesuai dengan permintaan pihak ketiga. Sebab, proyeksi fisik yang dikerjaan oleh pihak ketiga baru ditotal atau diambil pada akhir tahun. Karena itu serapan anggaran belum terlihat secara maksimal. Sementara, anggaran tertinggi APBD 2019 yakni Dinas Pendidikan yang mencapai Rp 627.055.947.000 baru menyerap anggaran Rp 309.327.364.089 atau 49.41\%. Kemudian, Kantor Kesatuan Bangsa dan Politik (KKBP) dengan anggaran terendah Rp 4.585.020.000 berhasil menyerap Rp 2.331.003.175 atau 60.01\%. Pihak pemerintah Bogor menyebut akan memperbaiki realisasi serapan anggaran di tingkat SKPD wilayah Bogor. Pemkot Bogor telah menyiapkan hadiah 
dan hukuman untuk menunjang kinerja setiap SKPD agar dapat memberikan motivasi bagi SKPD. Sehingga, jajaran SKPD dapat saling memaksimalkan anggaran.

Sedangkan untuk realisasi serapan anggaran pemerintah Kabupaten Bogor, terutama pada komponen belanja langsung dalam APBD 2019 hingga 9 Oktober, baru terealisasi Rp 1.51 triliun dari alokasi Rp 4.2 triliun. Sehingga anggaran belanja langsung baru terserap 38.95 persen. Rendahnya penyerapan anggaran disebabkan banyaknya pihak ketiga penyedia jasa yang belum mencairkan dana sesuai progress pembangunan dilapangan. Adapun untuk belanja pegawai, telah terealisasi Rp 208.928.897.598 atau 58,79 persen dari $\mathrm{Rp}$ 355.399.822.000. Sementara untuk belanja barang dan jasa telah terealisasi Rp 819.660.269.733 atau 37.79 persen dari anggaran Rp 2.169.229.056.800. Kemudian untuk belanja modal telah terealisasi Rp 482.521 .873 .339 atau 28.75 persen dari anggaran Rp 1.678.338.143.200. Berbeda dengan belanja langsung pada komponen belanja tidak langsung, dari alokasi Rp 3.7 triliun telah terserap Rp 2.04 triliun atau 54.98 persen. Sementara pada Pendapatan Asli Daerah telah terealisasi Rp 2.2 triliun dari target Rp2.6 triliun atau terealisasi 84.76 persen.

Pada tahun 2017 sampai tahun 2018 pelaksanaan program dan kegiatan untuk mewujudkan target kinerja yang ingin dicapai RSUD wilayah Bogor didukung dari Anggran Pendapatan dan Belanja Daerah (APBD) kota Bogor, bantuan keuangan Provinsi Jawa Barat, dana alokasi khusus sub bidang pelayanan kesehatan rujukan, dan dana bagi hasil cukai hasil tembakau. Adapun total anggaran yang dimilik RSUD wilayah Bogor untuk mendukung tercapai kinerja yang telah diperjanjikan adalah sebesar Rp 216.788.514.000 pada tahun 2017 dan pada tahun 2018 sebesar Rp 194.291.095.000 yang terdiri dari anggaran belanja tidak langsung dan belanja langsung, dengan komposisi pada Tabel 2.

Tabel 2. Rencana Anggaran RSUD Kota Bogor Tahun 2017-2018 (dalam Rupiah)

\begin{tabular}{lccc}
\hline Tahun & $\begin{array}{c}\text { Belanja Tidak } \\
\text { Langsung }\end{array}$ & $\begin{array}{c}\text { Belanja } \\
\text { Langsung }\end{array}$ & Total \\
\hline 2017 & 5.903 .699 .000 & 210.884 .815 .000 & 216.788 .514 .000 \\
2018 & 5.510 .805 .000 & 188.780 .299 .000 & 194.291 .095 .000 \\
\hline
\end{tabular}

Alasan dalam pemilihan variabel karena penelitian terdahulu tentang kinerja manajerial telah banyak dilakukan tetapi hasil dari penelitian tidak memberikan hasil konsistensi yang signifikan terhadap faktor-faktor yang mempengaruhi kinerja manajerial. Terdapat perbedaan hasil penelitian mengenai partisipasi anggaran dan reward terhadap kinerja manajerial. Hasil penelitian oleh (Nurul, 2012) menemukan bahwa partisipasi anggaran tidak berpengaruh terhadap kinerja manajerial. Sedangkan (Wisnu, 2015), (Ony, 2011), (Hanifatuz dan Indira, 2016), (Dita et al., 2016), (Aditya dan Linda, 2015), (Lilis dan Purwanto, 2013), (Nanik, 2017), (Anisa, 2013), (Putri dan Putra, 2015) dan (Zuwesty, 2014) menemukan bahwa partisipasi anggaran berpengaruh terhadap kinerja manajerial. 


\section{KAJIAN TEORI}

Teori Kontijensi. Menurut (Otley, 1995) yang dimaksud dengan teori kontijensi merupakan kerangka dan siste akuntansi manajemen yang dapat sebagai sarana informasi perusahaan dalam mencapai tujuan dan startegi dalam menghadapi persaingan. Pada penelitian terdahulu di bidang akuntansi teori kontijensi banyak dihubungkan dengan partisipasi penyusunan anggaran dengan kinerja manajerial. Salah satu faktor kontijensi yang dihubungkan dengan partisipasi penyusunan anggaran terhadap kinerja manajerial yaitu reward.

Teori Goal Setting. Menurut (Locke dan Latham, 1990) teori penetapan dapat membuktikan adanya keterkaitan antaran tugas yang diberikan dengan tujuan dan kinerja. Teori ini memaparkan terdapat dua faktor perilaku seseorang yaitu content (values) dan intentions (tujuan). Perilaku seseorang berpengaruh terhadap tindakan dan resiko yang timbul akibat kinerjanya sehingga akan memotivasi dalam peningkatan poduktifitas kinerja baik individu maupun kelompok. (Wardhana dan Syaparilwadi, 2015).

Teori Stakeholder. Menurut (Chariri dan Ghozali, 2007) teori ini menyatakan suatu organisasi tidak hanya memikirkan untuk kepentingan sendiri, tetapi harus memberikan manfaat kepada pemegang saham, kreditor, konsumen, supplier, pemerintah, masyarakat, analis dan pihak lain). Sehingga dengan adanya keberadaan suatu perusahaan dipengaruhi oleh dukungan yang diberikan stakeholders kepada perusahaan.

Pengelolaan secara maksimal untuk semua potensi, sebuah perusahaan akan dapat menciptakan value added yang kemudian mendorong kinerja keuangan dan nilai perusahaan yang berorientasi kepada stakeholder dalam mengintervensi manajemen (Gatot dan Ietje, 2018). Pemikiran pada teori stakeholder ini kurang lebih mengarah pada keberadaan suatu organisasi (dalam hal ini rumah sakit) yang sangat dipengaruhi oleh dukungan dari individua tau kelompok yang memiliki hubungan dengan organisasi atau perusahaan tersebut (Diska dan Irni, 2019).

Partisipasi Anggaran dan Kinerja Manajerial. Peran anggaran yang telah disusun memiliki perencanaa dan kriteria kinerja sebagai suatu sistem pengendalian untuk mengukur kinerja manajer. Menurut (Bambang dan Osmad, 2007); (Diponegoro, 2016) menyatakan bahwa dalam menentukan sikap dan perilaku anggota organisasi perlu melibatkan manajemen pada level yang lebih rendah sehingga dapat meningkatkan kinerja setiap anggotanya karena anggaran partisipasi dapat dinilai sebagai pendekatan manajerial. Salah satu unsur penting yang menekankan pada proses kerjasama dari berbagai pihak, baik dari bawahan maupun dari manajer level atas dapat disebut sebagai partisipasi. Keterlibatan bawahan, karena manajer level bawah yang mempunyai hak dan oeran dalam proses manajemen, karena anggaran melibatkan berbagai pihak yang terkait didalam penyusunan anggaran.

Kinerja Manajerial. Kinerja merupakan pencapain kinerja individu yang disesuaikan dengan tugas dan tanggung jawabnya dalam periode tertentu, yang berkaitan dengan ukuran nilai atau kriteria yang sudah ditetapkan oleh perusahaan (Dianawati dan Widowati, 2009). Menurut (Douglas dan Kariv, 2009) kinerja manajerial merupakan pengetahuan manajemen 
yang dapat mencerminkan keterampilan dan pengetahuan khusus dibidang manajemen dalam bentuk berbagai bentuk usaha.

Reward. Dalam hal ini suatu reward atau penghargaan dapat memberikan motivasi bagi karyawan sehingga dapat membantu karyawan dalam mengalokasikan waktu dan usahanya dalam melaksanakan tugas yang diberikan. Menurut (Mulyadi dan johny, 2011) Reward mendorong kinerja karyawan untuk meningkatkan kualitas kerja untuk memenuhi kepentingan individu maupun organisasi yang dapat memberi informasi dan motivasi. Reward dapat digolongkan ke dalam dua kelompok (Mulyadi, 2007) yaitu:

Reward Instrinsik (non-finansial). Berupa rasa puas diri terhadap seseorang karna telah berhasil mencapai atau menyelesaikan pekerjaannya dengan baik sehingga mencapai target tertentu. Pihak manajemen dapat menggunakan berbagai teknik Untuk meningkatkan penghargaan instrinsik yaitu seperti memberikan penambahan tanggungjawab, ikut terlibat dalam pengambilan keputusan, dan berbagai bentuk usaha lainnya yang dapat meningkatkan kualiats diri.

Reward Ekstrinsik (finansial). Terdapat dua kompensasi yang diberikan kepada karyawan terkait reward ekstrinsik berupa: (1) Kompensasi secara langsung yaitu berupa gaji atau upah, upah lembur, pembagian laba, pembagian saham dan berbagai bonus lainnya yang dilakukan secara pembayaran langsung kepada karyawan yang didasarkan atas kinerja karyawan. (2) Kompensasi secara tidak langsung, yaitu asuransi kecelakaan, asuransi hari tua, honorarium liburan dan tunjangan masa sakit semua pembayaran tersebut untuk kesejahteraan karyawan.

\section{METODOLOGI}

Terdapat dua variabel yang digunakan dalam penelitian ini yaitu variabel independen atau variabel yang dapat mempengaruhi, satu variabel dependen atau variabel yang hanya dapat dipengaruhi. Penelitian ini bertujuan untuk mengetahui serta membuktikan apakah terdapat pengaruh antara partisipasi dalam penyusunan anggaran sebagai dan reward variabel independent terhadap kinerja manajerial sebagai variabel dependen. Dalam penelitian ini pengolahan data menggunakan metode Regresi Linier Berganda. Jenis data yang digunakan yaitu data primer, berupa kuesioner dengan teknik survey serta jawaban langsung dari responden yang dilakukan di rumah sakit umum daerah wilaah Bogor yang terdiri dari RSUD kota Bogor, RSUD Cibinong, RSUD Leuwiliang, RSUD Ciawi, dan RSUD Cileungsi serta menggunakan data sekunder yaitu data yang sudah diolah melalui studi pustaka didalam penelitian ini. Jenis sampling yang digunakan adalah purposive sampling. Sampel dalam penelitian ini berjumlah 100 responden yang dibagian sebanyak 20 kuesioner disetiap rumah sakit dan hanya kembali sebanyak 85 kuesioner yang dapat diolah.

Variabel Independen. Menurut (Sugiyono, 2010) variabel independent merupakan variabel yang dapat mempengaruhi atau menjadi penyebab perubahan. Dalam penelitian ini terdapat dua variabel independent yaitu partisipasi penyusunan anggaran dan reward. Menurut (Bambang dan Osmad, 2007) proses penyusunan anggaran untuk melihat seberapa 
jauh tingkat keterlibatan dan peran aktif dari pengaruh manajer didalam bagiannya secara berkala baik secara periodic maupun tahunan. Dalam proses ini para manajer yang terkait akan melakukan negosiasi dengan pihak atasan untuk menetapkan target dalam pencapaian anggaran. Sedangkan reward dalam penelitian ini digunakan untuk melihat dengan adanya pemberian reward kepada karyawan akan meningkatkan kinerja manajerial.

Variabel Dependen. Variabel terikat menurut (Sugiyono, 2010) merupakan variabel yang dipengaruhi atau yang menjadi akibat karena adanyavariabel independen atau variabel bebas. Variabel dependen dalam penelitian ini adalah Kinerja Manajerial yang didefinisikan sebagai keluaran yang dihasilkan oleh manajer dalam melakukan fungsi manajemen (Wirawan, 2009). Kinerja manajerial yang dimaksud dalam penelitian ini adalah kegiatankegiatan manajerial yang meliputi: perencanaan, investigasi, pengkoordinasian, evaluasi, pengawasan, pengaturan staff, negosiasi dan perwakilan atau representasi (Mahoney 1993).

Variabel dalam penelitian ini akan membagi masing-masing variabel menjadi variabel operasional atau indikator hai ini bertujuan agara setiap variabel dapat diukur dan dianalisi. Lebih rinci lagi, berikut merupakan masing-masing variabel berserta indikator dan skala pengukuran dalam penelitian ini .

Tabel 3. Definisi Operational dan pengukuran Variabel

\begin{tabular}{|c|c|c|c|}
\hline Variabel & Definisi Operasional & Indikator & $\begin{array}{c}\text { Skala } \\
\text { Pengukuran }\end{array}$ \\
\hline $\begin{array}{l}\text { 1. Partisipasi dalam } \\
\text { Penyusunan } \\
\text { Anggaran }\end{array}$ & $\begin{array}{l}\text { Tingkat keterlibatan } \\
\text { dan pengaruh individu } \\
\text { dalam proses } \\
\text { penyusunan anggaran }\end{array}$ & $\begin{array}{l}\text { 1. Tingkat Partisipasi } \\
\text { 2. Kontribusi responden } \\
\text { 3. Revisi Anggaran } \\
\text { 4. Frekuensi diskusi }\end{array}$ & SkalaLikert \\
\hline 2. Reward & $\begin{array}{ll}\begin{array}{l}\text { Kompensasi } \\
\text { diberikan }\end{array} \text { kepada } \\
\text { manajer / } & \text { staf sesuai } \\
\text { dengan } & \text { penilaian } \\
\text { kinerja. } & \end{array}$ & $\begin{array}{l}\text { 1. Penilaian } \\
\text { 2. Kepuasan akan peng- } \\
\text { hargaan } \\
\text { 3. Pencapaian target }\end{array}$ & SkalaLikert \\
\hline 3. Kinerja Manajerial & $\begin{array}{l}\text { Hasil kerja yang dapat } \\
\text { dicapai individu dalam } \\
\text { perusahaan sesuai } \\
\text { dengan wewenang dan } \\
\text { tanggungjawab masing- } \\
\text { masing dalam rangka } \\
\text { mencapai tujuan } \\
\text { perusahaan }\end{array}$ & $\begin{array}{l}\text { 1. Perencanaan } \\
\text { 2. Investigasi } \\
\text { 3. Pengkoordinasian } \\
\text { 4. Pengawasan } \\
\text { 5. Penilaian staff } \\
\text { 6. Perwakilan } \\
\text { 7. Kinerja secara } \\
\text { keseluruhan } \\
\text { 8. Evaluasi } \\
\text { 9. Kinerja secara } \\
\text { keseluruhan }\end{array}$ & Skala Likert \\
\hline
\end{tabular}


Pada tabel 3 menunjukan bahwa untuk menentukan tingkat kemampuan setiap variabel ditentukan dari semua data pertanyaan berupa kuesioner yang diambil dari setiap indikator yang ditentukan. Penilaian setiap indikator ditentukan melalui skala likert satu sampai lima. Data yang sudah dikumpulkan akan di analisis menggunakan metode Regresi Berganda yang diolah dengan aplikasi program Eviews. Model kerangka konseptual dalam penelitian ini disajikan pada Gambar 1.

Gambar 1. kerangka konseptual

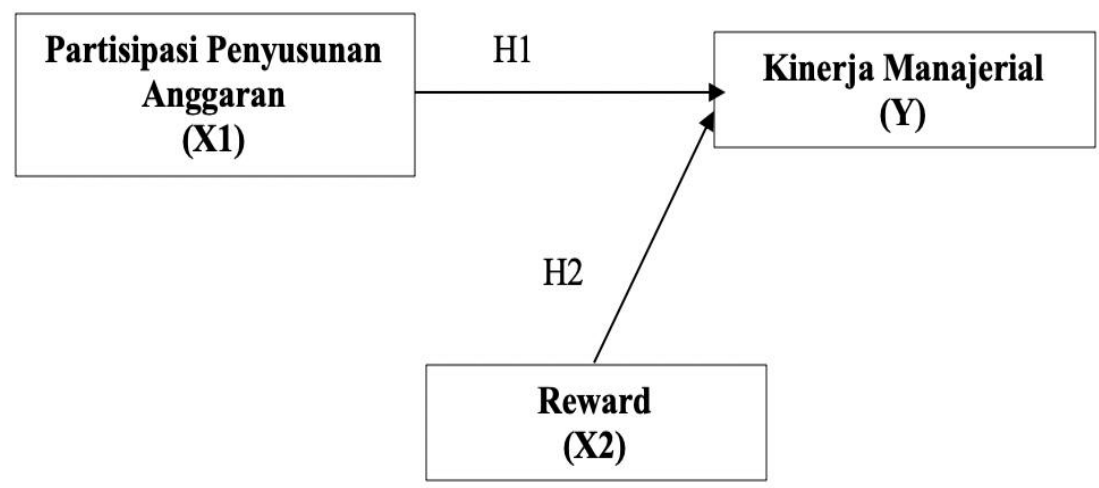

Berdasarkan latar belakang, permasalahan dan tinjauan pustaka, maka beberapa hipotesis yang diuji melalui penelitian adalah sebagai berikut: (1) Partisipasi dalam penyusunan anggaran berpengaruh terhadap kinerja manajerial. (2) Reward berpengaruh terhadap kinerja manajerial.

Uji Hipotesis. Model analisis data yang digunakan dalam penelitian ini adalah Model regresi Linier Berganda. Pada model analisis ini terdapat satu model regresi.

$\mathrm{Y}=\alpha+\boldsymbol{\beta}_{1} \mathrm{X}_{1}+\boldsymbol{\beta}_{2} \mathrm{X}_{2}+\mathrm{e}$

Keterangan dari persamaan diatas sebagai berikut:

$\mathrm{Y}=$ Kinerja Manajerial

$\mathrm{X}_{1}=$ Partisipasi Penyusunan Anggaran

$\mathrm{X}_{2}=$ Reward 


\section{HASIL DAN PEMBAHASAN}

Lokasi, Desain dan Waktu Penelitian. Alasan dipilihnya rumah sakit umum daerah diwilayah kota bogor yaitu karena rumah sakti merupakan organisasi yang bertujuan meminimalkan biaya dan memaksimalkan pelayanan sehingga karyawan dituntun lebih komitmen pada tujuan perusahaan, selain itu Bogor memiliki tingkat persaingan rumah sakit yang semakin kompetitif sehingga diperlukan perencanaan anggaran yang efektif dan berorientasi pada tujuan. Sedangkan waktu penelitian ini yaitu pada periode bulan Maret sampai April 2020. Penelitian ini dilakukan di lima RSUD wilayah Bogor yaitu RSUD Kota Bogor, RSUD Cileungsi, RSUD Ciawi, RSUD Leuwiliang, RSUD Cibinong.

Karakteristik responden. Dalam penelitian ini responden berasal dari manajer, kepala bagian, kepala sub bagaian dan karyawan yang ikut terlibat dalam penyusunan anggaran di RSUD wilayah Bogor. Responden yang sudah dilibatkan dalam penelitian ini yaitu sebanyak 85 tenaga kerja kemudian responden tersebut dipilih berdasarkan kriterianya yaitu: (1) Sekurang-kurangnya memiliki gelar sarjana ekonomi (2) pernah terlibat dalam penyusunan anggaran dan memiliki jabatan manajer tingkat menengah dan bawah. Sampel ditentukan dengan syarat sebagai berikut : (1) Rumah sakit tersebut merupakan rumah sakit umum daerah wilayah Bogor (2) Rumah sakit umum daerah yang terdaftar di Departemen Kesehatan RI.

Uji Validitas. Teknik untuk menguji validitas pada setiap penyataan mengguakan Pearson Product Moment dengan kriteria jika nilai yang dihasilkan dari setaip penyataan lebih besar dari r-kritis sebesar 0,3, maka dikatakan valid. Adapun hasil uji validitas kuesioner untuk variabel yang diteliti disajikan pada tabel

Tabel 4. Rekaputalasi hasil uji validitas partisipasi penyusunan anggaran

\begin{tabular}{ccccc}
\hline No & Pernyataan & rhitung & rktitis & keterangan \\
\hline 1 & Pernyataan 1 & 0,836 & 0,3 & Valid \\
2 & Pernyataan 2 & 0,869 & 0,3 & Valid \\
3 & Pernyataan 3 & 0,921 & 0,3 & Valid \\
4 & Pernyataan 4 & 0,860 & 0,3 & Valid \\
5 & Pernyataan 5 & 0,858 & 0,3 & Valid \\
\hline
\end{tabular}

Sumber: data Primer yang diolah tahun 2020 
Tabel 5. Rekaputalasi hasil uji validitas kinerja manajerial

\begin{tabular}{llccc}
\hline No & Pernyataan & rhitung & rktitis $_{\text {keterangan }}$ & Valid \\
\hline 1 & Pernyataan 1 & $\mathbf{0 , 8 8 0}$ & 0,3 & Valid \\
2 & Pernyataan 2 & 0,888 & 0,3 & Valid \\
3 & Pernyataan 3 & 0,838 & 0,3 & Valid \\
4 & Pernyataan 4 & 0,815 & 0,3 & Valid \\
5 & Pernyataan 5 & 0,874 & 0,3 & Valid \\
6 & Pernyataan 6 & 0,816 & 0,3 & Valid \\
7 & Pernyataan 7 & 0,867 & 0,3 & Valid \\
8 & Pernyataan 8 & 0,869 & 0,3 & Valid \\
9 & Pernyataan 9 & 0,886 & 0,3 & \\
\hline
\end{tabular}

Sumber: data Primer yang diolah tahun 2020

Tabel 6. Rekaputalasi hasil uji validitas Reward

\begin{tabular}{llccc}
\hline No & Pertanyaan & rhitung & rktitis & keterangan \\
\hline 1 & Pernyataan 1 & 0,805 & 0,3 & Valid \\
2 & Pernyataan 2 & 0,785 & 0,3 & Valid \\
3 & Pernyataan 3 & 0,755 & 0,3 & Valid \\
4 & Pernyataan 4 & 0,797 & 0,3 & Valid \\
5 & Pernyataan 5 & 0,764 & 0,3 & Valid \\
6 & Pernyataan 6 & 0,763 & 0,3 & Valid \\
7 & Pernyataan 7 & 0,763 & 0,3 & Valid \\
\hline
\end{tabular}

Sumber: data Primer yang diolah tahun 2020

Berdasarkan tabel 4, 5 dan 6 terlihat bahwa dari semua pernyataan pada variabel partisipasi penyusunan anggaran, kinerja manajerial dan reward memperoleh nilai koefisien validitas > 0,3, sehingga untuk semua pernyataan dikatan layak digunakan sebagai alat ukur dalam penelitian analisis regresi linear sederhana.

Uji Reliabilitas. Metode yang digunakan dalam uji reliabilitas yaitu metode AlphaCronbach. Kuesioner dikatakan andal apabila koefisien reliabilitas bernilai positif dan lebih besar dari pada 0,7. Adapun hasil dari uji reliabilitas disajikan pada Tabel 7. 
Tabel 7. Hasil Uji Reliabilitas Kuesioner Penelitian

\begin{tabular}{lccc}
\hline \multicolumn{1}{c}{ Butir Pernyataan } & $\begin{array}{c}\text { Koefisien } \\
\text { Reabilitas }\end{array}$ & Nilai kritis & keterangan \\
\hline (X) Partisipasi & 0,917 & 0,7 & Reliabel \\
penyusunan anggaran & & & \\
(Y) kinerja manajerial & 0,955 & 0,7 & Reliabel \\
$\left(\mathrm{X}_{2}\right)$ Reward & 0,889 & 0,7 & Reliabel \\
\hline
\end{tabular}

Berdasarkan Tabel 7 memperoleh bernilai positif dan lebih besar dari 0,7 untuk masing-masing varibel dari semua pernyataan yang diberikan kerpada responden. Hal tersebut menunjukan bahwa data dapat diterima dan hasil ini menunjukan untuk setiap oertanyaan oada kusioner dikatakan andal untuk mengukur variabel.

\section{Uji Asumsi Klasik}

Uji Normalitas. Dalam pengujin menggunakan uji normalitas untuk mengetahui apakah residual menyebar secara normal atau tidak. Uji yang digunakan salah satunya yaitu menggunakan uji Jarque-Bera.

Gambar 2. uji jarque-Bera

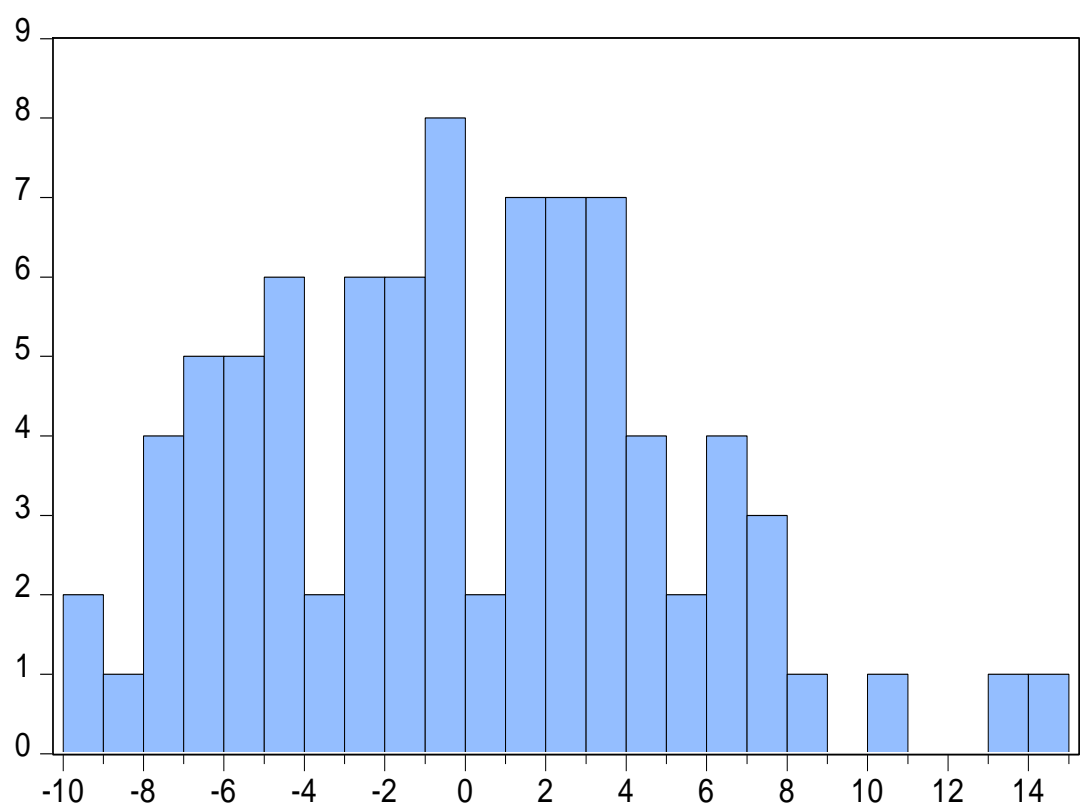

\begin{tabular}{|c|c|}
\hline \multicolumn{2}{|c|}{$\begin{array}{l}\text { Series: Residuals } \\
\text { Sample } 185 \\
\text { Observations } 85\end{array}$} \\
\hline Mean & $-6.13 e-15$ \\
\hline dian & -0.364054 \\
\hline aximum & 14.78143 \\
\hline nimum & -9.576984 \\
\hline Std. Dev. & 5.133472 \\
\hline Skewness & 0.369895 \\
\hline Kurtosis & 2.911142 \\
\hline & 1.966280 \\
\hline obability & 0.374135 \\
\hline
\end{tabular}

Hasil perhitungan diatas menunjukkan uji Jarque-Bera sebesar $(0.3741)>(0.05)$ maka keputusannya gagal tolak Ho, sehingga dapat disimpulkan asumsi normalitas terpenuhi.

Uji Multikolinieritas. Menururt (Gujarati, 2006) salah satu cara melihat adanya multikolinearitas dengan melihat nilai F-statistik yang signifikan, namun $\mathrm{t}$-statistik dari 
masing-masing variabel tidak signifikan (Gujarati, 2006). Disamping itu cara lain untuk mengetahui terjadi masalah multikolinieritas yaitu dengan melihat Variance Inflation Factor dari variabel independen. Jika memiliki kriteria dimana nilai VIF $>10=$ terdapat multikolinieritas. Berikut ditampilkan nilai VIF dari masing-masing variabel independent yang disajikan pada Tabel 8.

Tabel 8. hasil uji multikolinieritas

\begin{tabular}{cccc}
\hline \hline Variable & $\begin{array}{c}\text { Coefficient } \\
\text { Variance }\end{array}$ & $\begin{array}{c}\text { Uncentered } \\
\text { VIF }\end{array}$ & $\begin{array}{c}\text { Centered } \\
\text { VIF }\end{array}$ \\
\hline \hline X1 & 0.020563 & 15.67867 & 1.097899 \\
X2 & 0.014354 & 18.66940 & 1.097899 \\
C & 7.492885 & 23.59284 & NA \\
\hline \hline
\end{tabular}

Keterangan:

$\mathrm{X} 1=$ Partisipasi penyusunan anggaran

$\mathrm{X} 2=$ Reward

Berdasarkan hasil perhitungan yang disajikan pada Tabel 8 dapat disimpulkan bahwa tidak terjadi multikolinieritas antar variabel bebas dalam model. Memperoleh nilai VIF masing-masing variabel bebas dibawah 10 , yakni partisipasi penyusunan anggaran $(\mathrm{x} 1)=$ 1.097899 , reward $(\mathrm{x} 2)=1.097899$.

Uji Autokorelasi. Pengujian autokorelasi dalam penelitian ini dilakukan dengan statistic d dari Durbin-Watson. Adapun hasilnya disajikan pada Tabel 9.

Tabel 9. uji Durbin-Watson

\begin{tabular}{lrll}
\hline \hline R-squared & 0.457628 & Mean dependent var & 28.06261 \\
Adjusted R-squared & 0.444399 & S.D. dependent var & 6.970478 \\
S.E. of regression & 5.195698 & Akaike info criterion & 6.168195 \\
Sum squared resid & 2213.613 & Schwarz criterion & 6.254406 \\
Log likelihood & -259.1483 & Hannan-Quinn criter. & 6.202872 \\
F-statistic & 34.59387 & Durbin-Watson stat & 2.030894 \\
Prob(F-statistic) & 0.000000 & & \\
\hline
\end{tabular}

Berdasarkan Tabel 9 Durbin-Watson untuk $\mathrm{k}=2$ dan $\mathrm{n}=85$ diperoleh nilai $\mathrm{dL}=$ $1.5995 \mathrm{dU}=1.6957$. Dengan demikian hasil uji durbin Watson diketahui nilai DW-stat (2.0308). Karena nilai dw-stat berada diantara dU dan 4-dU yaitu $1.6957<2.0308<2.3419$ sehingga dapat disimpulkan bahwa tidak terjadi masalah autokorelasi.

Koefisien Determinasi. Menurut (Sugiyono, 2010) untuk melihat pengaruh suatu variabel terhadap variabel lain dapat disebut sebagai koefisien determinasi yang meruapakan 
kuadran dari koefisien korelasi. Dengan perolehan nilai $\mathrm{R}^{2}$ sebesar 0,4576 , maka hasil perhitungan koefisien determinasi disajikan pada Tabel 10.

Tabel 10. uji koefisien determinasi

\begin{tabular}{lrll}
\hline \hline R-squared & 0.457628 & Mean dependent var & 28.06261 \\
Adjusted R-squared & 0.444399 & S.D. dependent var & 6.970478 \\
S.E. of regression & 5.195698 & Akaike info criterion & 6.168195 \\
Sum squared resid & 2213.613 & Schwarz criterion & 6.254406 \\
Log likelihood & -259.1483 & Hannan-Quinn criter. & 6.202872 \\
F-statistic & 34.59387 & Durbin-Watson stat & 2.030894 \\
Prob(F-statistic) & 0.000000 & Wald F-statistic & 37.05039 \\
Prob(Wald F-statistic) & 0.000000 & & \\
\hline \hline
\end{tabular}

Nilai koefisien determinasi sebesar $45.76 \%$ yang menunjukkan arti bahwa pengaruh Partisipasi Penyusunan Anggaran dan reward sebesar 45.76\% terhadap Kinerja Manajerial. Sedangkan sisanya sebesar $54.24 \%$ dipengaruhi oleh faktor lain diluar penelitian ini.

Hasil Uji Hipotesis. Dalam pengujian hipotesis ini akan menjelaskan variabel-variabel penelitian secara komprehensif. Pengujian yang sudah dilakukan dan mendapatkan hasil menggunakan uji-t berikut rincian masing-masing hipotesis dan interpretasinya pada Tabel 11.

Tabel 11. Uji parsial (uji-t)

\begin{tabular}{ccccc}
\hline \hline Variable & Coefficient & Std. Error & t-Statistic & Prob. \\
\hline \hline X1 & 1.098706 & 0.143243 & 7.670240 & 0.0000 \\
X2 & 0.096117 & 0.136503 & 0.704138 & 0.4833 \\
C & 9.679840 & 2.884667 & 3.355618 & 0.0012 \\
\hline \hline
\end{tabular}

Partisipasi dalam penyusunan anggaran berpengaruh terhadap kinerja manajerial. (Yusfaningrum dan Gozali, 2005) Berdasarkan Tabel 11 untuk hipotesis pertama menyatakan bahwa partisipasi dalam penyusunan anggaran berpengaruh positif signifikan terhadap kinerja manajerial. Menurut (Bambang dan Osmad, 2007), anggaran dapat dipakai sebagai suatu sistem pengendalian untuk mengukur kinerja manajerial, sehingga penyusunan anggaran berperan sebagai suatu sistem perencaan dan kriteria kinerja suatu perusahaan. Sehingga, anggaran partisipasi merupakan salah satu pendekatan manajerial yang dapat meningkatkan kinerja setiap manajer sebagai sesuai dengan sasaran yang telah ditetapkan sebelumnya. Hasil penelitian ini sejalan dengan yang dilakukan oleh (Bambang dan Osmad, 2007) yaitu partisipasi anggran berpengaruh terhadap kinerja manajerial.

Reward berpengaruh terhadap kinerja manajerial. Terkait hipotesis reward tidak memiliki pengaruh yang signifikan terhadap varibel kinerja manajerial. dengan perolehan 
nilai memiliki nilai $p$-value $(0.4833)>0.05$. Artinya hasil penelitian ini tidak mendukung hipotesis yang kinerja manajerial akan meningkat ketika reward yang diberikan tinggi. Hal ini memungkinkan mengingat bahwa reward yang diberikan oleh rumah sakit bukan di dasarkan pada kinerja manajerial saja tetapi ada beberapa faktor lain yang mempengaruhinya seperti:

Lamanya bekerja. Lamanya bekerja seorang karyawan didalam suatu perusaahan sangat diperhitungkan oleh managemen sebab semakin lamanya tenaga kerja itu bekerja disuatu perusahaan maka dapat menggambarkan pengalaman seseorang dalam bidang yang ditugas kepadanya.

Keputusan managemen dalam penilaian kinerja karyawan. Dari semua keputusan yang diambil oleh pihak managemen perusahaan sangat berpengaruh besar dalam penilain kinerja setiap karyawan karena keputusan yang diambil tidak dapat diganggu gugat.

Motivasi karyawan. Memberikan reward atau penghargaan kepada karyawan pasti akan membuat para karyawan merasa senang, karena merasa pekerjaan yang dilakukannya dihargai dengan baik oleh perusahaan. Dalam pemberian reward maka perusahaan akan mendapatkan timbal balik dari karyawan yaitu dengan meningkatkan produktifias kinerja. Menurut hasil dilapangan motivasi karyawan tidak mungkin dapat dinilai dengan angka walaupun rumah sakit sudah menetapkan standar atau target disetiap tujuan yang ingin dicapai secara optimal. Penelitian ini didukung oleh penelitian yang dilakukan (Najafi, 2017) hasil dari penelitian tersebut menunjukkkan bahwa reward tidak berpengaruh terhadap kinerja manajerial.

\section{KESIMPULAN}

Penelitian ini bertujuan untuk melihat sejauh mana pengaruh partisipasi penyusunan anggaran dan reward terhadap kinerja manajerial pada rumah sakit umum daerah wilayah Bogor. Berdasarkan hasil temuan penelitian dan pengujian hipotesis yang telah dilakukan dapat disimpulkan bahwa: (1) Partisipasi Penyusunan Anggaran berpengaruh positif terhadap kinerja manajerial. Artinya, Partisipasi penyusunan anggaran merupakan keterlibatan para manajer dalam suatu organisasi dalam pencapaian tujuan dan sasaran yang telah ditetapkan dalam anggaran. Dengan demikian, semakin tinggi keterlibatan para manager terhadap partisipasi dalam penyusunan anggaran, maka akan mengakibatkan meningkatkan kinerja manajerial. Para manajer akan merasa lebih bertanggung jawab terhadap tugas-tugas yang diberikan karena ikut terlibat dalam proses partisipasi penyusunan anggaran sehingga merasa beratnggung jawab dalam mencapai sasaran anggaran. (2) Reward tidak berpengaruh bterhadap kinerja manajerial . Dengan demikian, bahwa s tinggi atau rendahnya reward yang diberikan kepada belum tentu dapat meningkatkan produktivitas kinerja mereka bagi organisasi, dalam hal ini RSUD wilayah Bogor. Hendaknya pihak instansi lebih memikirkan bagaimana cara memberikan reward kepada karyawan yang sesuai dengan prestasi kerja para karyawan.

Saran. Berdasarkan hasil penelitian ini, terdapat beberapa saran untuk penelitian selanjutnya, yaitu: (1) Terkait penyebaran kuesioner dalam penelitian ini belum mencakup 
seluruh rumah sakit wilayah Bogor. Penelitian selanjutnya dapat melakukan proses penyebaran kuesioner yang lebih luas dan dapat membandingkan dengan rumah sakit swasta wilayah Bogor. (2) Personil yang menjadi responden masih ada rasa takut dalam pengisian kuesioner, karena hampir semuanya jawaban responden berada diposisi sedang dan baik serta ada beberapa perosnil yang terlibat dalam pengangaran tetapi memilih tidak mengisi kuesioner tersebut. (3) Dengan tidak terbuktinya reward tidak berpengaruh terhadap kinerja manajeral maka penelitian selanjutnya dapat menguji variabel lain yang berpotensi positif anara partisipasi dalam proses penyusunan anggaran terhadap kinerja manajerial. (4) Pemberian reward berupa material sudah lama diberlakukan, karena reward yang diberikan kepada karyawan dirasakan semu karena dianggap sudah menjadi hak mutlak, sehingga tidak dijadikan sebagai motivasi karyawan dalam meningkatkan kinerja. Kesenjangan antara karyawan senior dan junior dengan pemberian reward yang didapat menjadi penyebab permasalahan dilapangan. Rumah sakit sebaiknya lebih meningkatkan jumlah besaran reward yang diberikan agar kinerja yang dihasilkan karyawan lebih meningkatkan.

\section{DAFTAR PUSTAKA}

Aditya C dan Linda S. (2015). Pengaruh partisipasi anggaran terhadap kinerja manajerial melalui komitmen organisasi dan motivasi sebagai varaibel moderating (studi empiris pada perusahaan manufaktur di Jakarta dan Tangerang). Jurnal Akuntansi. 19 (1): 144-159.

Annisa. (2013). Pengaruh Kejelasan Sasaran Anggaran dan Desentralisasi Terhadap Kinerja Pemerintah Daerah. Jurnal Akuntansi Universitas Negeri Padang.

Bambang Sardjito dan Osmad Muthaher. (2007). Pengaruh Partisipasi Penyusunan Anggaran Terhadap Kinerja Aparat Pemerintah Daerah: Budaya Organisasi dan Komitmen Organisasi Sebagai Variabel Moderating.

Chariri A dan Ghozali Imam. (2007). "Teori Akuntansi". Semarang: Badan Penerbit Universitas.

Dianawati dan Widowati. (2009). Studi Kelayakan Finansial Pengolahan Limbah Cair Tapioka Sebagai Nata De Cassava. Buana Sains. Vol 9, No 1.

Diponegoro Adi W. (2016). Partisipasi anggaran terhadap kinerja manajerial dengan komitmen organisasi, motivasi dan struktur desentralisasi sebagai variabel pemoderasi. Jurnal Akuntansi. 20(1): 150-166.

Diska Asmarni dan Irni Yusnita. (2019). Pengaruh Mekanisme Corporate Governance Terhadap Tingkatkepatuhan Pengungkapan Wajib Konvergensi Ifrs Padaperusahaan Hotel, Restoran Dan Pariwisata Yang Terdaftar Dibursa Efek Indonesia Periode 20142018. JURNAL EKONOMI SAKTI (JES). Volume 8 No. 1, 2019.

Dita Nafinia; Epi Fitriah; Rini Lestari. (2016). Pengaruh Partisipasi Penyusunan Anggaran dan Komitmen Organisasi Terhadap Kinerja Manajerial. Vol 2, No 2, Prosiding Akuntansi.

Douglas M. Gale and Shachar Kariv. (2009). Trading in Networks: A Normal Form Game Experiment. American Economic Journal: Microeconomics. vol. 1, no. 2, August 2009. (pp. 114-32) 
Gatot Ahmad Sirojudin dan Ietje Nazaruddin. (2018). Pengaruh Modal Intelektual dan Pengungkapannya Terhadap Nilai dan Kinerja Perusahaan. Journal of Accounting and Investment. Vol 15, No 2.

Ghozali I. (2005). Aplikasi Analisis Multivariate dengan program SPSS. Semarang (ID): Badan Penerbit Universitas Diponegoro.

Gujarati, Damodar N. (2006). Ekonometrika Dasar. Jakarta: Penerbit Erlangga. Teori Ekonomi Mikro. Terjemahan dari Microeconomic Theory.

Hanifatuz Zahro dan Indira Januarti. (2016). Pengaruh Partisipasi Anggaran Terhadap Kinerja Manajerial Dengan Persepsi Keadilan Anggaran Dan Komitmen Tujuan Anggaran Sebagai Variabel Intervening (Studi Kasus pada Universitas Diponegoro). Jurnal Akuntansi dan Auditing, 13(2): 125-154.

Lilis S dan Purwanto. (2013). Analisis pengaruh partisipasi penyusunan anggaran terhadap kinerja manajerial dan kepuasan kerja pada pemerintahan kota semarang. Media Ekonomidan Teknologi Informasi. 21(2): 66-79.

Locke E A and Latham GP (1990). A theory of goal setting and task performance. Englewood Cliffs New Jersey (UK): Prentice-Hall.

Mahoney. (1993). Development of managerial performance: A Research Approach. Cincinnati (US): South Western Publishing.

Mulyadi dan Johny. (2011). Sistem perencanaan dan pengendalian manajemen. Jakarta (ID): Salemba Empat.

Mulyadi. (2007). Sistem perencanaan dan pengendalian manajemen: sistem pelipatganda kinerja perusahaan. Jakarta: Salemba Empat.

Nafinia. (2016). Pengaruh Partisipasi Penyusunan Anggaran dan Komitmen Organisasi terhadap Kinerja Manajerial. Prosiding Akuntansi. Vol 2. No. 2.

Najafi S, Alvandi M. (2017). The impacts of self-concept on brand image and loyalty with mediating role of the consumers' need for uniqueness theory. Business nnovatin and Research. 13(4): 519-537.

Nanik E. (2017). Pengaruh Partisipasi Penyusunan Anggaran Terhadap Kinerja Manajerial Dengan Motivasi Kerja Sebagai Varaibel Pemoderasi (studi kaus SKPD kabupaten Pati). Jurnal Akuntansi Indonesia. 6(2): 141-156.

Nurul Azizah. (2012). Pergeseran Kepemimpinan Ulama Menjadi Umara. Lisan Al-Hal: Jurnal Pengembangan Pemikiran dan Kebudayaan 6 (1), 99-100.

Ony Kurniawati. (2011). Pengaruh Partisipasi Anggaran, Komitmen Organisasi, Dan Gaya Kepemimpinan Terhadap Kinerja Manajerial Pada PT. X Surabaya. Jurnal Ilmu Ekonomi Pembangunan 2 (2), 142-148

Otley D. (1995). Management control, organization design and accounting information system. New Jersey (UK) Prentice Hall.

Putri MS dan Putra WA. (2015). Pengaruh partisipasi penganggaran pada kinerja manajerial. E-Jurnal Akuntansi Universitas Udayana. 12(2): 435-451.

Rahayu, Sri dan Andry Arifian Rachman. (2013). Penyusunan Anggaran Perusahaan. Yogyakarta: Graha Ilmu.

Sugiyono. (2010). Metode Penelitian Pendidikan Pendekatan Kuantitatif, kualitatif, dan $R \& D$. Bandung(ID): Alfabeta.

Wardhana A, dan P Syaparilwadi. (2015). Pengaruh Kualitas Produk terhadap Kepuasan Pelanggan pada Perusahaan Konveksi Fazry. Jurnal Administrasi Bisnis 1 (1), 2015. 
Wirawan. (2009). Evaluasi Kinerja Sumber Daya Manusia Teori Aplikasi dan. Penelitian. Jakarta. Penerbit: Salemba Empat.

Wisnu Tri Yunianto. (2015). Pengaruh Partisipasi Penyusunan Anggaran, Komitmen Organisasi dan Gaya Kepemimpinan Terhadap Kinerja Manajerial. Jurnal Ilmu dan Riset Akuntansi. Vol.4 No.1 2015.

Yogi A. (2018). Analisis pengaruh partisipasi penyusunan anggaran terhadap kinerja manajerial dengan kepuasan kerja, job relevant information dan kepuasan kerja sebagai variabel moderating. [tesis]. Semarang (ID) Universitas Diponegoro.

Yusfaningrum K dan Gozali I. (2005). Analisis Pengaruh Partisipasi anggaran Terhadap Kinerja Manajerial melalui Komitmen Tujuan Anggaran dan Job Relevant Information (JRI) Sebagai Variabel Intervening. Simposium Nasional Akuntansi 8, Padang.

Zuwesty Eka. (2015). Analisis Pengaruh Pendapatan Asli Daerah (PAD), Dana Alokasi Umum (DAU), dan Inflasi terhadap Pertumbuhan Ekonomi di Kabupaten/Kota Provinsi Jawa Tengah. Esensi Jurnal Bisnis dan Manajemen. Vol. 5, No. 2. 